\title{
Totalitarian Propaganda as Discourse
}

\section{A Comparative Look at Austria and France in the Fascist Era}

\author{
ALEXANDER HANISCH-WOLFRAM
}

\section{Introduction}

Throughout the $20^{\text {th }}$ century, propaganda has been a key term and a key concept of political communications studies; ${ }^{1}$ in certain respects, propaganda research actually stood at the cradle of this field of social science (Bussemer: 2005: 379-385). At the same time, propaganda as a specific mode of communication was at the centre of totalitarianism as a political phenomenon, which attained its peak in the first half of the same century. Totalitarian propaganda-best explored in the cases of National Socialism and Soviet Communism-had the function of creating consensus between political leadership and the masses.

In this paper, totalitarian propaganda will first be identified as a specific type of political communication which can be described and analyzed as a discourse. However, the theoretical position will be presented in such a way as to make it clear that the discourse-analytical approach represents only one possible way of operationalizing the underlying theoretical concept of propaganda. In what follows, the proposed definition will be further described in theoretical terms and operationalised along the so-called "dimensions of propaganda". Concerning the empirical part, the focus will be placed on a restricted choice of these dimensions, in order to be able to go into more detail and depth in presenting the examples. The two texts chosen for a comparative illustration of the

1 | For an overview over the traditions of propaganda theory and research: Bussemer: 2005. 
approach are two speeches pronounced under comparable historical circumstances (in Austria in the 1930s and in France in the early 1940s). In conclusion, the perspectives of the approach described will be elaborated.

\section{Defining (Totalitarian) Propaganda}

There have been various "waves" or phases in propaganda research throughout the $20^{\text {th }}$ century, each of them having its own definitions of "propaganda" - or even explicitly refusing to define the term or the phenomenon. $^{2}$ This, in combination with the ubiquitousness of the term in political debate, has led to a certain degree of confusion about what "propaganda" can mean, should mean or must not mean. The model of propaganda research proposed here has the basic aim of laying out an interdisciplinary theory of propaganda as a basis for empirical social research. ${ }^{3}$ The central theoretical concept on which this theoretical approach to propaganda is based is "collective identity" (Giesen 1999; Straub 1998; Wodak, Cillia and Reisigl 1998: 47-71). Thus, propaganda shall be defined here as the strategically planned attempt to construct, spread and implement a certain collective identity, combined with the use of various forms of pressure or even violence.

The degree of detail and complexity in the elaboration of this identity can vary, as can the use of pressure or force to implement it. This, in consequence, leads to a broad variety of types of propaganda, one of them being totalitarian propaganda.

Within this broad variety of types, totalitarian propaganda is the most elaborated and most complex one. Totalitarian propaganda consequently is to be understood as a complex and elaborated communication strategy aimed at promoting and implementing a collective identity encompassing (nearly) all aspects of life-from political opinions and attitudes to values and ways of life in the private sphere. ${ }^{4}$

For theoretical description as well as for empirical analysis, different

2 | For a short overview over the main paradigmes: Bussemer 2005: 43-60.

3 | For a more detailed elaboration of this propaganda model: Hanisch-Wolfram: 2006a: 3-73; Hanisch-Wolfram 2007: 55-98.

4 | As the phenomenon of totalitarianism in general, totalitarian propaganda also touches upon the question of the relationship between the public and the private spheres. As a detailed discussion of this issue would lead beyond the objective of this paper, it shall just be noted that in general this relationship itself has to be understood as a discursive construction; totalitarianism basically aims 
dimensions of propaganda can be specified. These dimensions belong to different levels of communicating propaganda, some of them referring to modes of communication and other pointing at its content. These dimensions are:

1. Myths and rituals (Hanisch-Wolfram 2006a: 45-53; Hanisch-Wolfram 2007: 65-77). Myths ${ }^{5}$ play a central role in (totalitarian) propaganda as they provide a basis of belonging together which is notin danger of being questioned. What is communicated as a myth lies beyond verification and also beyond the need for legitimization. Myths provide answers to the questions of the collective's roots, origins, common characteristics and goals, they may even give reasons for the "choice" of the enemies. Propagandistic myths can take various forms, from simple key words hinting at whole narratives or stereotypes, to the historical key dates and events or symbolic places. Ritual serves as an actualization of the contents narrated in mythic communication. In rituals, myths are arranged in order to visualize their meaning and importance for the contemporary social life. Examples of such rituals include manifestations of memorial culture or the organization of (political) events in symbolic historical areas.

2. Signs and symbols (Hanisch-Wolfram 2006a: 55-57; HanischWolfram 2007: 77-81; Frutiger 2006). As with personalization, this dimension of propaganda is essentially reduction of complexity. In this case, the visualization is not realized by presenting a certain person or group of persons, but by establishing and then propagating certain graphic designs or symbols. These symbols have a twofold function: firstly, they represent an element of the ideology being propagated (or even this ideology as a whole, as e.g. the swastika); secondly, they enable the propagandist (especially if this is a regime already in power) to be omnipresent on a symbolic level.

3. The construction of the "Other" (Hanisch-Wolfram 2006a: 42-45;

at abolishing the differentiation between the public and the private, and so does totalitarian propaganda.

5 | It would lead too far here to discuss in depth the various concepts and definitions of the "myth"; basically, "myth" shall be defined here as a concept of a (great) narrative that is use in social discourse in an axiomatic way. Myths in this sense need not be legitimized or proven, they are themselves the basis of legitimation and proof. 
Hanisch-Wolfram 2007: 81-86). For a given (or “planned”) group to define itself, it is first of all necessary to define what it is not-or what it must not be or become. This central operation of group identification (Karall 2001; Luhmann 1994) is intensified within propaganda communication by the construction of an enemysomething or someone not only different but hostile (Wendt 2006; Schlee 2006). This "other" has to be combatted in order to stabilize the group. The intensity of this combat varies from discrimination to planned annihilation.

4. Construction of the common history (Hanisch-Wolfram 2006a: 49-51; Hanisch-Wolfram 2007: 71-73). This dimension of propaganda is closely linked to mythic communication. Narrating the past always implies a choice of events, in some cases even the definition of what is to be seen as a historical event and what is not (Chris 1997: 17-64, 367-436; a constructivist perspective is elaborated e.g. in: Assmann 1999). In case of propaganda, this choice is made with the aim of supporting the collective identity to be implemented. As a positive choice, this means the commemoration of certain events, processes and dates linked to this identity; as a negative choice, it implies the radical eliminationof all events, persons or dates conflicting with this identity, from collective memory. This may mean re-writing history books and destroying or building monuments (Menkovic 1999; for the authoritarian regime in Austria, discussed as one of the examples below see: Grassegger 1998), but also re-interpreting historical events in order to make them fit into the intended definition of social cohesion.

5. Personalization of propaganda elements (Hanisch-Wolfram 2006a: 53-55; Hanisch-Wolfram 2007: 86-89). This dimension of propaganda is basically a strategy of reduction in complexity. Ideological dogmas, historical references or myths are reduced to a given person, name or image. This person or image, after being effectively established by propaganda, then stands for its recipients for the entire cluster of conscious or unconscious references, values, stereotypes and connotations. As with historical dates, there might be established a pantheon of canonized persons which express the core of the collective identity to be implemented in a human form (Behrenbeck 1996; For one of the examples discussed below see: Cointet 2002). The most prominent example of this type of 
propaganda communication is the cult of "great leaders"-from Lenin and Stalin to Hitler or Mao.

It seems quite obvious that these dimensions of propaganda are intended to be ideal types which are rarely realized as such; usually, they are are combined, with large overlapping areas. For example, a given personalization can at the same time be a personalized myth-as was the case with Hitler oder Mao. Another example might be the use of symbols or personalizations which take their roots from collective historical traditions. Finally, the definitions and presentations of enemies are often personalized and legitimized through historical references.

\section{Totalitarian Propaganda as Discourse}

Basically, the theoretical approach to the phenomenon of propaganda delineated above is meant to be an interdisciplinary approach to the foundations of various (social) scientific disciplines working on propaganda. A common definition can make it possible to reach a higher level of comparability regarding the results of specific studies, which then in turn can be a basis for further development of the theoretical approach as such.

In this paper, the specific methodological approach chosen is a discourse-analytical study of propaganda (Hanisch-Wolfram 2006b; Hanisch-Wolfram 2007:184-205). In this vein, propaganda can be understood as a socio-political discourse, with a focus on its verbal form(s). It has to be underlined again that this is the only possible way of implementing the proposed theoretical concept in the concrete empirical research.

Although discourse analysis-especially the Critical Discourse Analysis, ${ }^{6}$ focuses primarily on questions of social power (political power being understood as one of its forms), it has until now quite rarely taken up the issue of propaganda (Hanisch-Wolfram 2006b: 86-87). At first sight, this is quite surprising, as propaganda is one of the most prominent and (in other disciplines) most researched political phenomena, at least as far as $20^{\text {th }}$ century is concerned. One of the reasons reason for this lack of interest might be the fixation of CDA on various forms of

6 | It is im impossible to give a selected bibliography for (Critical) Discourse Analysis here. For a general overview, which is related to the approache(s) used in this study, see among others: Fairclough 1995; Fairclough 2001; Jäger 1993; Wodak and Meyer 2001. 
hidden social power making, aimed at disclosing the invisible forces of social control. Having this specific task in mind, it seems more natural that propaganda as a form of social control or a way of exerting social power is a too "overt" phenomenon to come into the focus of critical discourse analysis.

However, at the same time, CDA provides a set of methods which can be made very fruitful for propaganda analysis and make it possible to deliver innovative research results. Its basic interest fits in with the outlined concept of propaganda: "CDA may be defined as fundamentally concerned with analysing opaque as well as transparent structural relationships of dominance, discrimination, power and control as manifested in language" (Wodak 2001: 2). The concept of "text" used by CDA expresses the same social-constructivist approach that governs a concept of propaganda as the construction of collective identity. It is not only the text as such that is to be analyzed, but the relationship between producers, recepients and channels of communication, as well as the process of constructing common definitions of reality emerging from interaction between these three (Hanisch-Wolfram 2007: 110). Basically, it can be stated that "propaganda discourse" refers to the production, dissemination and reception of specific propaganda texts that are intended to spread and implement a certain definition of collective identity (and, henceforth, of social reality), accompanied by various forms of control in and over discourse as well as other, non-discoursive forms of social control.

The question of power in and over discourse relates to the control a propagandist strives to exert over political communication (Fairclough and Wodak 1997: 272-273). Power over discourse refers to the 1) ways of controlling its accesssibility, 2) eligible participants and 3) extent of participation. In order to control political discourse and freely spread propaganda, the propagandist will seek to exert a rather drastic power over discourse, which means a lot of discrimination and exclusion. In the case of totalitarian propaganda, the access to discourse will be restricted to those recognized as loyal to the regime in power and thereby officially sanctioned to take part in this discourse (in the Third Reich, for instance, this was regulated mainly by the so-called "Schriftleitergesetz"7). Power in discourse, on the other hand, implies controlling the content of discourse, including the breakdown of vocabulary into words to be used

7 | For the implementation of tis law in Austria after March 1938, see: Hausjell 1993: 40-53. 
and words to be avoided. In totalitarian propaganda, there might even be a precise catalogue of allowed and forbidden notions (as was the case, again, with the Third Reich). Through this control over ways of communication, definitions of reality can be manipulated as certain terms are no longer parts of discourse, whereas other terms, due to their connotations, are the references to the description of social reality. On the other hand, the terms excluded from propaganda discourse can-as such-become symbols of resistance and opposition.

The basic discoursive strategy of propaganda discourse is a constructive strategy which first of all aims at constructing and implementing a certain collective identity (Wodak, Cillia and Reisigl 1998: 82-86). Beyond this constructive strategy, other strategies of discourse can also come into play, especially if the propagandist already holds power-as is the case with totalitarian propaganda. In this case, there can also be strategies of conservation aimed at stabilizing and strengthening the regime in power (Wodak, Cillia and Reisigl 1998: 87-88).

The realization of a propaganda discourse cannot, however, simply aim at putting pressure on the recipients in order to reach its goal. For a common definition of reality and, in particular, of planned identity, the recipients have to be convinced that they voluntarily take part in this identity - even though power and coercion are, in fact, the key elements in its implementation. This can be realized through a strictly controlled social discourse, a major part of it being the propaganda discourse. In its turn, the most controlled form of discourse is reached in the form of totalitarian discourse.

The dimensions of propaganda described above can be understood as strata of discourse. Generally, the strata of discourse-a concept elaborated by the Duisburg school of discourse analysis (Jäger 1993: 181-187, 208-209) — are to be seen as different components and facets of one discourse which are inextrucably tied together and can only be fully understood in this perspective. This matches the dimensions of propaganda outlined above, which also have to be understood as ideal types which in practice exist only overlapping with one another and therefore must be interpreted in the context of the other facets of the intervowen whole realized in a given text.

This short outline of a discourse-analytical approach to propaganda research should have shown in what ways different concepts of critical discourse analysis can lend theoretical as well as methodological support for propaganda analysis; its aim was also to demonstrate that the study of propaganda can open up a new field of research for discourse analysis. 


\section{Illustration \\ Austria and France in the Fascist Era}

Focus of the Illustration

As already mentioned, the elaboration of the empirical examples illustrating the concept described above will be focused on a limited choice of the "dimensions" of propaganda. This will make it possible to elaborate the comparison in more depth and detail. Besides, as there is always an interplay between the different dimensions of propaganda, the other ones which are not focused on explicitly will not be neglected completely.

The dimension chosen for a more detailed interpretation is the propagandistic myth. The main reason for this choice can be seen in the fact that quite often the myths realized in a given propaganda text represent a kind of nucleus or core of the propagandistic topoi realized in this text. Another reason is that propagandistic myths are particularly close to other dimensions of propaganda. One will rarely find a myth in a given piece of propaganda which is not linked to at least one of its other dimensions. Thus, the interwovenness of the different dimensions of propaganda can be best illustrated through an analysis of propaganda myths. This analysis would lead to elaboration of the basic typology of propaganda myths, which, in their elaborated form, should be understood as no more than ideal types which in reality are closely knit together, with large overlapping areas.

As the focus in the following empirical analysis will be put on propaganda myths, the other dimensions will only be discussed in a rather general way. Despite this generality, though, it could be discerned to what extent the interconnectedness between the different dimensions represents a central characteristic of propaganda discourse and what forms the other dimensions can take.

\section{A Comparative look at Austria and France}

The two texts chosen for a comparative empirical analysis are taken from the propaganda discourses of the two state systems which are not the classical full-blown totalitarian regimes and have therefore largely eluded the grasp of propaganda research. These systems are the authoritarian quasi-fascist regime in Austria (1933-1938) (Talos and Neugebauer 2005; concerning the Propaganda of the regime, see: Kriechbaumer 2002; Hanisch-Wolfram 2006a: 252-266) and the Vichy regime in France, led 
by Marshall Pétain (1940-1944) (Cointet 2003; Paxton 1997; Azéma and Bédarida 1992; concerning the Propaganda of the Vichy regime see: Rossignol 1991). Regarding the respective historical contexts, there is a considerable degree of comparability between the two as both regimes existed in the context of the rising fascism (or quasi-fascism) in Central and Western Europe, which, in its turn, was overshadowed by the rise and peak of National Socialism in Germany. They were also both influenced by the Nazi Regime, albeit in very different ways and situations.

The Austrian text chosen is a speech held by chancellor Engelbert Dollfuß in Vienna on September $11^{\text {th }}, 1933$ in which he sets out the ideological foundation of the new regime. ${ }^{8}$ The French example is an address given by Philippe Pétain on August $12^{\text {th }}, 1941$ (known as the address about "le vent mauvais"), in which he legitimized the political project of his regime and severely criticised an oppositional mood of the general population. ${ }^{9}$

The comparative analysis undertaken in the following will be structured in such a way that those types of myths elaborated in both texts will be described first, followed by those types of myths which are only elaborated in one of the texts. Possible reasons for the differences will be discussed, and finally the already mentioned typology of myths will be outlined. This typology will go beyond the myths analyzed on the basis of the two chosen texts, because several types of propaganda myths are not present in these examples.

A first type of propaganda myth develope in both texts is the legitimizing myth (pertaining to the regime in power), combined with a sacrifice topos. In the case of the Pétain text, this myth is extremely personalized: Pétain describes his taking power as a sacrifice ("don de ma personne"), which he has to make in order to fulfill a duty. ${ }^{10}$ His career and image as a war hero (he was known to the French public as the general who defeated Germans at Verdun in 1915) surely affected the use of these topoi of sacrifice and duty. In sum, Pétain presents himself as the saviour of his country - a role he had already played in 1915. In the speech of Dollfuß, on the other hand, a similar myth is elaborated more in relation to a collective leadership: compared to the large number of "I"s in the Pétain text, Dolfuß generally prefers to use "we" as self-reference. There

8| The text is published in: Berchtold 1967: 427-433.

9 | For a detailed discourse analytical study of the text: Hanisch-Wolfram 2007: 289-317.

10 | For the role of Pétain in Vichy Propaganda see: Rossignol 1991: 77-112; for a more general discussion see: Cointet 2002. 
are two myths legitimizing the regime construed by Dollfuß. First, the new leadership is described as the result of God's will, which makes the whole enterprise mythological and sacred due to its mere existence. Second, the group of leaders now in power is characterized as being ready to sacrifice themselves ("opferbereit").

In sum, although the same myth is unwrapped in both texts, there are also significant differences. In the Austrian text, the new regime is referred to as a collective and is described (and legitimized) in religious, sacralizing terms. In the French text, on the other hand, Pétain as an individual leader is the focus of the myth, and the aspect of sacrifice is set more in military than in religious terms (although there certainly was a great deal of sacralizing Pétain the leader in Vichy propaganda).

A second type of myth which can be identified in both texts is the historical myth, which, however, has significant variations. In the Austrian text, the feudal structure of the early Modern Ages is presented as a harmonious, calm and just social order which ceased to exist in the course of the French Revolution (presented as the symbolic end of the Golden Age) (Kriechbaumer 2002: 49-53). This positive description of a distant historic era has a legitimizing function: the Golden Age is to be restored by the regime in power. This connection between the past and the future is one major function of the propaganda myth: the regime strengthening or stabilizing its power places itself in the flow of time linking its future projects to the past legitimating foundations. Another dimension of propaganda which is more or less explicitly linked to this myth is the rejection of various ideologies arising in the $19^{\text {th }}$ century.

In the Pétain text, in contrast, the historical myth is much less pronounced, being referred to only implicitly. Within the elaboration of the myth of the National Revolution and the myth of the war as a challenge (which will both be discussed below), the immediate past of the Third Republic (which ended in 1940) is described as the "ancien régime", i.e. the regime which had to be overcome in order to restore the glory of the nation. Thus, the motive for elaborating this historical myth is the same as in the Dollfuß text, but it is only mentioned implicitly and, even more importantly, within a framework of a negative historical myth.

Two other myths, or types of myths, in both texts include the dimension of a projected future. First, there is the creation of a new order-a goal which is rendered non-debatable by being presented as a myth. In the case of Vichy propaganda, the key term is the project of the "National Revolution" ("la Révolution Nationale” (Rossignol 1991: 113-166) ), which is, from that standpoint, is a "National Renovation" for it strives to 
restore the Golden Age of France by abolishing the disastrous effects of the French Revolution. The equivalent of this ideological project in concrete, "real" politics is the "new order" ("l'ordre nouveau") which as such is also presented as a myth. These two myths legitimize and support each other, in a way, they are interdependent in describing the future realization of the National Revolution (which, as Pétain states, remains uncompleted): the necessary to establish the new order is legitimized by the need to bring about the National Revolution. This Revolution stands as a kind of transcendent aim which is to be reached by creating a new social structure. This myth also shows the connection between different dimensions of propaganda. Pétain enumerates two main reasons why the National Revolution has not yet been fully realised: firstly, it is the absence of the prisoners of war (which is by itself a strongly personalized myth), and, secondly, the loalty of some to the "ancien régime".

In the Austrian text, this mythologized creation of a new order is explicitly linked to the mythologized past: the new order to be created is the restoration of the old feudal social order, which was already mentioned as an idealized past which had been lost. Unlike Pétain, Dollfuß overtly formulates the claim to restore a past situation. The difference can be illustrated on the level of the terms used in the texts: whereas Dollfuß refers to the notions connoting the social structure of the early Modern Age ("ständisch"), Pétain uses the term "révolution" which at least suggests a radical, progressive change-even if, in fact, both political projects are of a conservative nature aimed at restoring the old political structures.

The second kind of future-oriented myths developed in both texts is the description of a mythologized challenge or task. In the Dollfuß text this, on the one hand, is the already mentioned restoration of the old feudal social order and, on the other hand, the topos of a religious mission which Austria has to fulfill. Since these political (or ideological) plans and projects are not presented as the political will or projects of a certain social group, but rather as duties which the entire society has to fulfill, they become sacred tasks or challenges. This, in turn, places them beyond any debate or criticism, underscoring their totalitarian nature: opposition is no longer seen as the expression of a different political opinion, but rather as a violation of the sacred, a sin.

In the case of Pétain's text, this sacralization of the regime's political project, is even more elaborated. The first part of it is the already mentioned project of the National Revolution and the "ordre nouveau" as its political equivalent. This project is described by the Chef de l'Etat 
not merely in terms of political plans or concepts, but as a historic duty of all Frenchmen to restore the former glory of France and to arrest the political, cultural and social decline in the country triggered by the French Revolution and its consequences; National Revolution, so to speak, is the last chance of the French to save their nation. The topos of a mythologized task is overtly inscribed by Pétain in the actual political context-the war is presented as a challenge. Here again, we see a strong military undercurrent of Vichy propaganda, which paints the war and occupaiton resulting from not primarily as a disaster or a catastrophy but rather as a challenge which the French nation has to withstand, if the nation at all is worthy of restoring of its Golden Age. In this respect, the elaboration of this sacralized challenge has the function of exhortation.

Finally, there is a fourth propaganda myth of this category: throughout the text, the vision of a new, emerging Europe is mentioned (Rossignol 1991: 177-185). The leading role of Germany within this new Europe is taken for granted-and in any case, the challenge for the French nation is to prove itself again worthy of taking part in this "new Europe"-a construction to be finished after the end of the war. The role of the French nation within this new Europe outlined by Pétain contradicts in many aspects the restoration of French grandeur in the course of the National Revolution. The contradiction, however, can be seen as typical for propaganda discourse, known to gloss over conflicting claims and facts by sacralizing diffuse ideas, terms and projects. Because the latter are parts of a transcendent political sphere, there is no need for a reflection on their compatibility with reality—as long as propaganda works.

In addition, there are three types of myths which can only be identified in the Austrian text. The first is the ontological propaganda myth-a discoursive element claiming that certain characteristics belong "naturally" to individuals or collectives. These characteristic traits are presented not as the results of processes, but rather as the natural or god-given traits. The first such myth in the Dollfuß text is the myth of Austria's German character. That Austria is part of the German nation, and that it is a German state, is, according to Dollfuß, so self-evident that it goes without saying (which he does nonetheless). This stressing of the German character of Austria is at least partly rooted in the fact that the authoritarian regime had constituted itself after the Nazi seizure of power in Germany and that it should have been seen, from its beginnings, as a rival to the German model. The Dollfuß regime intended to present Austria as the "better Germany", as the guardian of the "true" German character. In this 
context a sub-myth had to be identified - that of the Christian-German character of Austria (Kriechbaumer 2002: 49-53). Austria as a state and part of the German people is described and defined as the better Germany precisely because it defines itself not only as a German state but also as a Christian (i. e. Catholic) state. The definition of what is German is thus transferred into the sphere of religion, for the "true" German character is represented as being Christian as well. Whether everyone in Germany or Austria perceived "German" to be defined in this way is of no interest to propaganda discourse: it is not claimed that Austria should be a German and Christian state, but that it is-by nature-a German and a Christian state. This, in the logic of this propagandistic discourse, is not a question of consent or dissent, but of natural characteristics.

The second ontological myth to be found in the text is closely linked to the first one: it is the myth of the religious and Christian nature of man. This myth is clearly to be interpreted in close relation to the one mentioned above: as the human being is said to be religious by nature and the Austrian regime claims to be a Christian/Catholic regime (unlike Nazism in Germany), the Austrian regime, unlike the Nazi regime, corresponds to the nature of the human being. The conclusion "our regime fits the human condition" need not be stated-its confirmation can be left to recipients. In any case, this ontological myth strengthens the ideological orientation of the regime and its propaganda myth of being the "better Germany".

Another type of myth, quite similar to the ontological myth, is the myth of positive or negative characteristic traits-which are not ascribed to an individual or a collective, but are given a great amount of importance and an incotestable value in propaganda discourse. In the case of the Dollfuß text, this is realized in two cases: the myth of calm and order and the myth of honesty. Both characteristics are presented as being extremely positive and-of course - as being characteristic traits of the social situation established by the regime. What is typical about this type of propaganda myth is that there is no explanation of what is meant by this term or what its points of reference are; it is just a term that is presented as positive or negative and that can be attached to a person, a regime, a situation etc. It is this vagueness that hinders discourse and makes this value statement a propaganda myth.

Finally, a third type of propaganda myth, found only in the Austrian example, is the mythologization of abstract concepts-in this case the concept of "Heimat" (a German word simultaneously referring to home, home country, nation, region, descent etc.). At the same time, this is 
a semantic myth, a term or word transformed into a myth; in the case of such a propaganda myth, the connotations which are evoked in the minds of the recipients are of utmost importance: for every recipient, there is a whole cluster of connotations, so that with the use of one single term or concept, a broad variety of feelings, ideas and value judgements can be triggered. In propaganda discourse, the propagandist will seek to manipulate and control discourse in such a way that those connotations will be strengthened-ideally, to the point of exclusiveness which would fit into his definition of social reality and collective identity.

Finally, there is one type of myth present only in the text from the Vichy propaganda: the personalized myth. There are three different myths of this category in this text; first and most prominent, there is the myth of Philippe Pétain as the saviour of France (which was already mentioned above). This myth is a typical example of the mythologization of a political leader in (totalitarian) propaganda-one might even claim that propaganda is totalitarian to the degree the respective leader is sacralized. In the case of Pétain's person there is also a strong military aspect, but nonetheless the aspect of sacrifice ("don de la personne") is of great importance. That there is no equivalent myth elaborated in the Dollfuß text is not typical for the propaganda of the authoritarian Austrian regime, which also puts its leading figure at the forefront, with the intensity greatly increased after Dollfuß's death in 1934 ("the dead man leads us") (Kriechbaumer 2002: 57-59, 64-66).

A second personalized myth in the Pétain text is the myth of the prisoners of war ("prisonniers de guerre"). They are presented as a significant element of social cohesion and a role model for the ideal character, sacrificial and patriotic at once. This personalized myth has also a transcendent character, as those on whom the myth is built are not present in France, they are away from home-and this further strengthens their character of being role models (especially regarding the topos of sacrifice). The third personalized myth which is only briefly mentioned in the text is that of the farmers, the "paysans". This has to be seen in connection with Pétain's personal roots in a rural area and the ideology of the National Revolution which stressed the importance of the French soil and farmers as guardians of this soil.

\section{A Typology of Propaganda Myths}

On the basis of the comparative analysis undertaken above, and of other results of discourse-analytical propaganda research, it is possible to 
formulate a typology of propaganda myths-which is intended to be open for further development on the basis of further research. At this stage, the following propaganda myths may be differentiated:

- The mythologized term, notion or concept. One key word or notion can be transformed into a myth in order to "freeze" its connotations and constrain variety of meanings. In this respect, the aspect of power in and over discourse is of great importance, since the propaganda apparatus will seek to minimize the range of different connotations to a reduced spectrum which is compatible with the intended social identity. In the case of an imaginary complete success of totalitarian propaganda, all words uses and meanings are dictated by the propagandist. The mythologization of abstract concepts can be seen as a sub-category of this myth; it is a type of myth which also serves as a support of and legitimation for other myths or other dimensions of propaganda.

- The personalized myth. This myth is closely linked to the propaganda dimension of personalisation. In certain cases, such a personalization can be heightened into a myth — with the person in question then being beyond any debate or criticism. This quite often goes hand in hand with the sacralization of a leading figure, which is very typical for totalitarian regimes.

- Historical myths. In conjunction with the construction of a common past as one dimension of propaganda, certain events, periods or processes of this past can be transformed into a myth. This generally concerns those parts of the common past which are defined as having a key role-which can also be a negative one, as is the case with the French Revolution in both texts discussed above. Besides, a canon of historical events and processes forming a historical myth is established by propaganda: certain facts or events are assigned fixed definitions and non-debatable (within propaganda discourse) interpretations.

- The myth of the origins or descent. A common descent or origin is an important aspect of strengthening social cohesion and to giving more weight to the collective identity constructed by propaganda. In most cases, this common descent is more or less a fiction, as it is either far from reality or beyond the possibility of being proven, or both. In the case of a propaganda myth, a certain theory of common origins is propagated and excluded from debate. 
- The legitimatory myth. This type of myth is generally used to support other dimensions of propaganda and form the basis for concrete political action. Without the necessity of being proven, these myths provide a set of reasons why the regime in question is in power, why it must stay in power and why it is legitimate for this regime to realise its political projects. The legitimatory myth is often combined with other myths, especially historical myths.

- The ontological myth. This myth ascribes to individuals, collectives, places etc. certain characteristics which-as was outlined above-are not presented as the result of processes or influences which are seen as natural or God-given. When applied to specific persons and things, these characteristic traits cannot be debated or altered. Other dimensions of propaganda and political action can then be build upon these characteristics: for instance, the enemy can be constructed in such a way that the differences between the group and the "others" would seem insurmountable, and so these "others" represent a danger which must be fought because communication and compromise are impossible. One type of myth very closely linked to this one is the aforementioned myth of certain characteristics which are then linked in a more or less absolute way to the specific value judgements.

- The myth of the collective future. These myths refer to "historical missions", the destiny of a collective and other similar concepts. They can take the form of challenges, unavoidable destinies or duties which have to be fulfilled. In combination with myths of origin, historical myths and ontological myths, propaganda discourse can chart on on the basis of propaganda myths alone an axis of temporal continuity of the collective.

- Local myths. Just as persons can be the objects of mythologization, certain places or regions can also provide the starting point for the creation of propaganda myths. In the elaborated propaganda myth, this geographical point of reference then is connoted to the specific events, persons, values etc. In consequence, the mention of this geographical term in propaganda discourse triggers an entire set of connotations for the recipients of this discourse. The places, being the point of reference for local myths, generally also play an important role in propaganda rituals.

- Object myths. The mythical objects regularly play a role within 
propaganda rituals. In such cases, artefacts serve as the points of reference for propaganda myths, the underlying semiotic process being equivalant to the case of the local myth or the personalized myth.

\section{Conclusion}

This paper had two intentions-to present a theoretical approach to the phenomenon of (totalitarian) propaganda on an interdisciplinary basis and to outline the specific approach of discourse-analytical propaganda research. The second is seen as an illustration of one possibility of operationalizing the outlined concept.

Due to the limited space, one of the described dimensions of propaganda was chosen as a focus. The choice fell on the propaganda myth as one central dimension of propaganda which was frequently is closely linked and interwoven with other dimensions of propaganda. This interdependence between the different dimensions of propaganda is to be seen as a significant element of this theoretical approach. The distinction between these dimensions has its reason primarily in practical analytical needs and the need to operationalize the theoretical concept. After the analysis of a given piece of propaganda, the different dimensions of propaganda have to be put together again with the aim of envisioning the whole palette of the propaganda in question. Each piece of propaganda analysed subsequently can then deliver further pieces for this mosaic and add details to the whole picture of the propaganda discourse. This concerns empirical data as well as theoretical questions.

What is also of importance for the concept proposed in this paper is that propaganda is not simply to be interpreted as one form of political communication, but as a complex process of social engineering and an attempt to create and implement a more or less artificial collective identity. It is evident that propaganda will hardly be successful in implementing a collective identity constructed out of void; it has to be anchored in pre-existing social structures, value and belief systems, social hierarchies and so forth. The more complex such a propagated collective identity is, the more aspects of the individual's life it touches upon, and the more this propaganda can be labelled 'totalitarian'. "True" totalitarian propaganda will not stop at manipulating social lives and political attitudes of the individuals concerned, but will also seek to influence their private lives. Perhaps the most tragic empirical example 
here is the antisemitic propaganda of the Nazi regime, which was aimed at positioning Jews as pariahs even in the most intimate spheres.

Just as totalitarianism has to be understood as a phenomenon of social engineering, of profound manipulation of people's attitudes, values and self-definitions, propaganda-and especially totalitarian propagandais a phenomenon of social communication with the potential of influencing to a high degree the definition of individual and especially collective identities. Discourse-analytical propaganda research is one way of uncovering this process, especially due to the critical impetus of discourse analysis. Further pursuing this approach can be fruitful for both sides (propaganda research and discourse analysis) — and subsequently for the social study of propaganda in general.

\section{References}

Assmann, J. 1999. Das kulturelle Gedächtnis. Schrift, Erinnerung und politische Identität in frühen Hochkulturen. München: Beck.

Azéma, J.-P. and F. Bédarida (editors). Le régime de Vichy et les Français. Paris: Fayard.

Behrenbeck, S. 1996. Der Führer. Die Einführung eines politischen Markenartikels. In Propaganda in Deutschland. Zur Geschichte der politischen Massenbeeinflussung im 20. Jahrhundert, edited by G. Diesener and R. Gries, 51-78. Darmstadt: Wissenschaftliche Buchgesellschaft.

Berchtold, K. 1967. Österrreichische Parteiprogramme 1868-1966. München: Oldenbourg.

Bussemer, T. 2005. Propaganda. Konzepte und Theorien. Wiesbaden: VS. Cointet, M. 2002. Pétain et les Français 1940-1951. Paris: Perrin.

Cointet, J.-P. 2003. Histoire de Vichy. Paris: Perrin.

Fairclough, N. 1995. Critical Discourse Analysis. The Critical Study of Language. London: Longman.

Fairclough, N. 2001. Language and power. Harlow: Longman.

Fairclough, N. and R. Wodak. 1997. Critical Discourse Analysis. In Discourse as Social Interaction. Discourse Studies. A Multidisciplinary Introduction. Volume 2, edited by T. van Dijk, 258-284. London: Sage.

Frutiger, A. 2006. Der Mensch und seine Zeichen. Wiesbaden: Marixverlag. 
Giesen, B. 1999. Kollektive Identität. Die Intellektuellen und die Nation 2. Frankfurt am Main: Suhrkamp.

Grassegger, F. 1998. Denkmäler des autoritären Ständestaates. Repräsentation staatlicher und nationaler Identität Österreichs 1934-1938. In Steinernes Bewußtsein I. Die öffentliche Repräsentation staatlicher und nationaler Identität Österreichs in seinen Denkmälern, edited by S. Riesenfellner, 495-546. Wien: Böhlau.

Hanisch-Wolfram, A. 2006a. Postalische Identitätskonstruktionen. Briefmarken als Medien totalitärer Propaganda. Frankfurt am Main: Lang.

Hanisch-Wolfram, A. 2006b. Die (Kritische) Diskursanalyse in der Propagandaforschung. Eine Nutzbarmachung. Quo vadis, Romania? 27: 86-100.

Hanisch-Wolfram, A. 2007. Pensez français, pensez Pétain! Diskursanalytische Studien zur Propaganda des Vichy-Regimes 1940-1944. Vienna: Praesens.

Hausjell, F. 1993. Journalisten für das Reich. Der "Reichsverband der deutschen Presse" in Österreich 1938-1945. Vienna: Lit-Verlag.

Jäger, S. 1993. Kritische Diskursanalyse. Eine Einführung. Duisburg: Unrast.

Karall, P. H. 2001. Konstruktionen “des Fremden”. Zwei Ansätze zur Untersuchung eines diffusen Phänomens. medien \& zeit 1: 48-60.

Kriechbaumer, R. 2002. Ein Vaterländisches Bilderbuch. Propaganda, Selbstinszenierung und Ästhetik der Vaterländischen Front 19331938. Wien: Böhlau.

Lorenz, C. 1997. Konstruktion der Vergangenheit. Eine Einführung in die Geschichtstheorie. Köln: Böhlau.

Luhmann, N. 1994. Inklusion und Exklusion. In Nationales Bewußtsein und kollektive Identität. Studien zur Entwicklung des kollektiven Bewußtseins in der Neuzeit 2, edited by H. Berding, 15-45. Frankfurt am Main: Suhrkamp.

Menkovic, B. 1999. Politische Gedenkkultur. Denkmäler. Die Visualisierung politischer Macht im öffentlichen Raum. Wien: Braumüller. Paxton, R. O. 1997. La France de Vichy. Paris: Seuil.

Rossignol, D. 1991. Histoire de la propagande en France de 1940 à 1944. Paris: Presses Universitaires de France.

Schlee, G. 2006. Wie Feindbilder entstehen. Eine Theorie religiöser und ethnischer Konflikte. München: Beck.

Straub, J. 1998. Personale und kollektive Identität. Zur Analyse eines theoretischen Begriff. In Identitäten. Erinnerung, Geschichte, Identität 
3, edited by A. Assmann and F. Heidrun, 73-104- Frankfurt am Main: Suhrkamp.

Talos, E. and W. Neugebauer (editors). 2005. Austrofaschismus. PolitikÖkonomie-Kultur 1933-1938. Wien: Lit-Verlag.

Wendt, D. 2006. Feindbild. Seine biologischen und psychologischen Ursachen. In Symbole der Politik, Politik der Symbole, edited by R. Voigt, 73-87. Opladen: Leske + Budrich.

Wodak, R., R. de Cillia and M. Reisigl. 1998. Zur diskursiven Konstruktion nationaler Identität. Frankfurt am Main: Suhrkamp.

Wodak, R. 2001. What CDA is about. A Summary of its History, Important Concepts and its Developments. In Methods of Critical Discourse Analysis, edited by R. Wodak and M. Meyer, 1-13. London: Sage.

Wodak, R. and M. Meyer (editors). 2001. Methods of Critical Discourse Analysis. London: Sage. 